\title{
Cooperative Federalism and Co-optation
}

\author{
Susan Rose-Ackerman $\uparrow$
}

Believing that grants-in-aid to state and local governments disarm the opposition of local elites and are thus of dubious constitutionality, Professor Cover asserts that the federal government ought to do more itself. However, his admonition that the federal government "ought to do more" is very vague. Would Gover like to eliminate all grants-in-aid? If not, what principles would guide his choice? Are direct federal orders to the states with no accompanying subsidy funds really preferable to the regulatory strings attached to spending programs? When should federally funded and administered programs preempt state and local initiatives and when should they merely supplement them? I propose a way to think about these unanswered questions and suggest that Cover's concerns are misplaced. Ending "cooperative" federalism would be unlikely to increase the political accountability of federal politicians significantly and could have a number of detrimental effects.

I argue the following propositions. First, federal action can help prevent states from benefiting at the expense of other states. Second, the federalization of redistributive programs, while justifiable on other grounds, would weaken, not strengthen, the states. Third, if Cover means to substitute federal legal orders for grants, this change in intergovernmental relations could encourage irresponsible behavior by national politicians. Fourth, to the extent intergovernmental grants would continue under Cover's system, they would have to take the form of revenue sharing with no restrictive conditions attached. Such transfers, if done on a large scale, would encourage irresponsible behavior by state and local politicians. Finally, even restrictive grants may not constrain the choices of state and local politicians very much. Federal money can substitute for state spending, thus freeing locally generated funds for other programs, and state officials may even be able to use the presence of federal grants to generate added public support for their own favorite projects. In practice, cooperative programs might not buy off opposition, but instead support the objectives of state political elites.

+ Professor of Law and Political Economy, Columbia University. 
Cover sees states as political units that can, in certain circumstances, challenge national power: State and nation ought to be politically combative. He forgets that, absent national controls, the combat may be among the states. States may compete for business and population and seek to impose external costs-such as air and water pollution or taxes-on residents of other states. We might call this "irresponsible federalism." Of course, neighboring states can form interstate compacts to regulate their relations, but these have not been notably successful in the past. While interstate port, bridge, and tunnel authorities have worked fairly well because states have reciprocal interests, compacts governing river use-for example, in the Delaware or the Colorado-have worked less well because of inevitable conflicts of interest. Thus, federal legislation may be needed to prevent the interstate imposition of external costs. The whole point of such laws is to "co-opt" state political processes, doing so to protect the interest of citizens of other states. This could be done by direct orders, by orders promulgated as a condition for grants, or by taxes (levied, for example, on pollution transported across state lines). Thus, grants are one way in which the federal government can "buy off" the state. Silencing state opposition is the purpose of such grants, not an undesirable side effect. ${ }^{1}$

II.

Many existing grant programs, however, have nothing to do with inducing states to take interstate spillovers into account. Instead, they are designed to redistribute income and services to the needy. It is a commonplace in the economic analysis of federalism to point out that state and local governments are poor instruments of redistributive policy. To quote the opinion in Helvering v. Davis: "[S]tates and local governments are at times reluctant to increase so heavily the burden of taxation to be borne by their residents for fear of placing themselves in a position of economic disadvantage as compared with neighbors or competitors."2 Furthermore, if a welfare or old age program exists in one state, it becomes "a bait to the needy and dependent elsewhere encouraging them to migrate and seek a haven of repose."s These concerns, combined with Cover's fears of cooptation, argue in favor of federal preemption of redistributive functions.

1. For a fuller discussion of these issues, see Mashaw \& Rose-Ackerman, Federalism and Regulation, in THE REAGAN REgulatory STRATEgy: AN ASSESSMENT (G. Eads \& M. Fix, eds.) (forthcoming).

2. 301 U.S. 619,644 (1937).

3. Id. 
The argument for preemption is further buttressed if one wishes a horizontally equitable system. Medicaid, for example, although funded in part by the federal government, gives the states considerable leeway to determine eligibility and covered services, and the result is wide variation in the treatment of the poor across the country. ${ }^{4}$ In addition, administrative efficiency argues in favor of a single system instead of dual state and federal programs with beneficiaries having to qualify separately for each set of services. In fact, even if a dual system were established, states might voluntarily use federal eligibility standards. They do this now in the tax area, where many state income tax systems track the federal law quite closely. ${ }^{5}$

Notice, however, that states purchase their freedom from federal intervention at considerable cost. If the federal government begins to take full responsibility for social welfare spending and preempts the states, the result is likely to be weaker and hence less combative state governments. Such preemption would reduce the financial and political resources at the disposal of state governments.

\section{III.}

Cover is not clear about what kinds of federal-state relations would develop if grants were reduced. He does, however, mention the other "enumerated" powers, and the implication is that, under these powers, the federal government could order the states to behave in certain ways. The substitution of legal orders for grants in certain areas would make state politicians complain noisily, a result that Cover seems to equate with political responsibility. It would, however, surely make national politicians less responsible. In fact, the recent federal programs that have caused the most controversy and opposition at the state level are those with small appropriations tied to large regulatory strings. The Education for All Handicapped Children Act of $1975^{\circ}$ and the 1978 amendments to the Developmental Disabilities $\mathrm{Act}^{7}$ have both been criticized on this ground, and a few jurisdictions have refused grants under these programs. ${ }^{8}$ An expansion of programs of this kind, not designed to correct specific inter-

4. J. Holahan, Financing Health Care fOR THE POOR 11-23 (1975).

5. See G. BREaK, Financing GovernMEnt in a FEDERAl System 37-39 (1980).

6. Pub. L. No. $94-142,89$ Stat. 773 (1975) (codified as amended at 20 U.S.C. $\$ \S 1401$, 1411-1420, 1453 (1982)).

7. Pub. L. No. $95-602,92$ Stat. $2955,3003-17$ (1973) (codified as amended at 42 U.S.C. $\S \S$ 6000-6081 (Supp. V. 1981)).

8. See Rose-Ackerman, Mental Retardation and Society: The Ethics and Politics of Normalization, 93 ETHICS 81, 94-96 (1982); Roach, The Least Restrictive Environment Section of the Education for All Handicapped Children Act of 1975: A Legislative History and an Analysis, 13 GONZAGA L. REV. 717,719 (1978). 
state externalities, would, I believe, be a mistake. Such legislation is relatively easy for Congrss to pass because legislators can take credit for bold, new initiatives without having to face up to the problem of finding tax money to cover the costs of those programs. It would hardly seem much of an improvement to make the regulatory orders mandatory and eliminate the small grants. The national political process would be improved by increasing, not decreasing, the accountability of political actors, even for laws justified under some enumerated power other than the spending power.

\section{IV.}

Cover would apparently favor a system in which intergovernmental grants took the form of revenue sharing based on rigid demographic formulas with no federal strings. Such grants would further Cover's goals by increasing the resources available to states and localities without a corresponding increase in federal control. State and local politicians could then criticize the national government without inviting retaliation. Indeed, revenue sharing programs are frequently resisted by national politicians, since they reduce their control over federal tax monies, and are applauded by governors and mayors because they provide a painless increase in resources. However, although more extensive revenue-sharing might increase the political power of state and local politicians, it would also increase the potential for irresponsible spending decisions by these politicians. Moreover, if states have unequal wealth, the most effective federal policy is to redistribute income to citizens, not to give funds to governmental units that may prove to be poor representatives of lowincome groups. ${ }^{\circledR}$

\section{V.}

Finally, Cover's concerns about "cooperative federalism" seem misplaced. Even earmarked grants, nominally designed to overcome state opposition to a federal program, may have little impact on state behavior. To see this, consider what federal officials commonly call the "fungibility problem." To illustrate this "problem," consider a lump-sum grant that must be spent on a particular service. If the grant is less than a state's pre-grant spending on that service, the state can treat the federal money as

9. Studies show that, despite formulas that take "need" into account, revenue sharing does not aid low-income groups very much. See R. NATHAN, A. MANVEL \& S. CALKINS, MONITORING REvenUE SHARING 237-47 (1975); R. NATHAN \& C. ADAMS, REVENUE SHARING: THE SECOND ROUND 67-75 (1977). The formulas are reported in Reischauer, General Revenue Sharing: The Program's Incentives, in Financing THE NEW FEDERALISM 40, 41-56 (W. Oates ed. 1975). 
if it were an untied increase in resources. The state can simply shift its own tax money into other programs. This "fungibility" problem is a severe limit on the federal government's ability to control state behavior: It tends to diffuse the effects of the federal money, thus blurring the differences between lump-sum grants and revenue-sharing grants. ${ }^{10}$

In addition, empirical work suggests that clever state and local politicians can use federal money to further their own political goals, and not, as Cover suggests, that federal money silences state and local opposition. Considerable evidence supports the proposition that lump-sum grants have "price" effects. ${ }^{11}$ In other words, state governments appear to behave "as if" the grants lowered the marginal cost of services. This has been called the "flypaper" effect: Money sticks where it hits. The idea behind the effect is that governmental insiders (politicians, bureaucrats, and perhaps organized interest groups that would benefit from increased spending) will manipulate the data so that voters perceive an illusory price effect and hence support higher levels of spending. ${ }^{12}$ Thus, instead of the federal government co-opting state and local political elites, these groups can use the federal grants to fool the populace into accepting more spending for elite-dominated programs.

10. Closed-ended matching grants-that is, grants in which the federal government agrees to match state spending only up to a certain ceiling-share this difficulty. Indeed, once the ceiling is exceeded, the grant operates just like a lump-sum grant.

11. See Gramlich, Intergovernmental Grants: A Review of the Empirical Literature, in THE POLITICAL ECONOMY OF FISCAL FEDERALISM 219 (W. Oates ed. 1977); S. Rose-Ackerman \& R. Evenson, Public Support for Agricultural Research and Extension: A Political-Economic Analysis (1983) (unpublished manuscript on file with Yale Law Journal).

12. Courant, Gramlich \& Rubinfeld, The Stimulative Effects of Intergovernmental Grants: Or Why Money Sticks Where It Hits, in FISCAL FEDERALISM AND GRANTS-IN-AID 5 (P. Mieszkowski \& W. Oakland eds. 1979); Oates, Lump-Sum Intergovernmental Grants Have Price Effects, in id. at 23. 